MARRIAGE AND DIVORCE - NULLITY - CONFLICT OF LAWS

\title{
- EFFECT OF STATUTE FORBIDDING MARRIAGE WITHIN TIME ALLOWED FOR APPEAL FROM DIVORCE DECREE
}

\author{
Fred Hochachica, Third Year Law
}

In 1867 the legislature of British Columbia passed an ordinance adopting for the colony the laws of England as of Nov. 19, 1858 "so far as they were not from local circumstances inapplicable". ${ }^{2}$ The laws so taken included The Divorce and Matrimonial Causes Act of 1857." Having been in force in the province for nearly a century one would hardly expect the applicability of any portion of the Act to remain open to serious doubt. Yet such doubt formed one of the major issues in the recent case of Hellens v. Densmore."

The facts of the case are brief. The appellant, being divorced by a British Columbia court, married the respondent in Alberta within the two month period in which a British Columbia statute purported to forbid such marriages. This time period was the time allowed for appeal. The appellant at the time of the marriage had acquired a domicile in Alberta where the respondent was also domiciled. Some five years later, the appellant brought action in a British Columbia court asking for a declaration of nullity with respect to this second marriage.

The Supreme Court of Canada, in a 4.3 judgment, held that although the British Columbia provision was ultra vires, s. 57 of The English Divorce and Matrimonial Causes Act containing analogous provisions applied to British Columbia, that this made the divorced parties subject to a residual incapacity to remarry, that Alberta was bound to recognize this incapacity, and that, in the result, as one party was incapable of marrying according to the laws of the domicile, i.e. Alberta, the marriage was therefore void. The dissenting Judges held s. 57 to be inapplicable to British Columbia and thus could find no impediment to the marriage. While the result in this case seems to be perfectly sound, the reasoning of the Court is open to serious criticism.

To begin with, s. 57 of the English Act provided that divorced parties could remarry after but not before "the time hereby limited for appeal". The time so referred to was a three month period provided by s. 56 of the Act which allowed appeals from the English court hearing divorce petitions to the House of Lords. The composition and name of the English court was different from any existing in British Columbia in 1867, and the appeal provision was similarly inape to application in the colony. Such apparene difficulties in applying the Act to British Columbia, however, have long since been held to constitute no bar to a general application of its substantive provisions. Thus in Watts v. Watts the Privy Council held that the Act did give the British Columbia court jurisdiction to hear divorce petitions.

But these were not the only difficulties with regard to s. 57. The in.

'English Las Ordinance (1867) Ordinances of British Columbia, 30 Vict., no. 7 (re. published as no. 70, Compiled Laws of British Columbia, 1871).

2The Dirorce and Matrimonial Causes $A d t$ (1857), 20 and 21 Vict., c. 85.

sHellens v. Densmore [1957] S.C.R. 768.

4 Watts v. Watts [1908] A.C. 573. 
capacity to marry provided here was directly related to a right of appeal; and it was to be effective only so long as the right to appeal subsisted, there being machinery capable of giving effect to such right. In 1867 British Columbia had no Court of Appeal. When created, the provincial Court of Appeal therefore held that it had no jurisdiction to hear divorce appeals as such jurisdiction could only be given by the Dominion Parliament in exercise of its powers over "marriage and divorce"." This question in itself is purely academic now for Dominion and Provincial legislation in 1937.38 put the question beyond dispute. But its determination is important in deciding whether or not 5.57 was applicable to British Columbia. For if there was no machinery for exercising a right of appeal until 1885 and no right of appeal in existence until 1937, then it is difficult to see how any substantive rule depending for its efficacy and meaning upon the existence of such machinery and such right can nevertheless be applicable. It is surely carrying the doctrine of "dormancy" to dangerous extremes to say that the rule, that there is an incapacity during the time limited for appeal, is in force in any way whatever, if in fact no right to appeal and no way of exercising such right exists.

Yet this is precisely the reasoning used by the Supreme Court and by Sidney Smith J.A. in the Court of Appeal." The latter indicated a dislike of the Scott v. Scott rule but proceeded to give judgment on the assumption that it was valid. Cartwright J., speaking for three Judges of the majority in the Supreme Court, summed up his opinion as follows:

" . . . S. 57 of the Imperial Act continues to operate in British Columbia mutatis mutandis, that the incapacity to marry, until the time for appealing from a dectee dissolving a marriage has expired .. . forms part of the substantive law of marriage and divorce in British Columbia which, while dormane so long as there was no right of appeal, became effective immediately upon that righe coming into existence."

The Chief Justice similarly thought a decision on Scott v. Scott was unnecessary. Locke J. and Abbott J. were more consistent in this respect and finding that there was nothing to impugn that decision went on to hold s. 57 inapplicable. The only criticism of this aspect of their judgment is their apparent failure to seriously consider the propriety of the Scott v. Scott rule. Rand J., who gave the only other judgment of the majority, thought a right of appeal could have been given by the province though for purposes of this case it was unnecessary to decide what legislature gave this right.

As it was open to the Supreme Court to overrule Scott v. Scott, it is submitted that their conclusion would have been much more logical had they done so. While the factors relating to the provision of divorce appeals in British Columbia are different from those in the other prairie provinces in that when the English law was introduced in these other provinces they already had a Court of Appeal (a point overlooked in Bilsland v. Bilsland" where the Manitoba Court of Appeal refused to follow Scott v. Scott), it seems clear that the right to judicial divorce created by the English Act of 1857 was not bereft of a

sScolt v. Seott (1891) 4 B.C.R. 316.

oSub nom.Densmore v. Densmore (1956) 19 W.W.R. 252 at 254 et seq.

i Hellens v. Densmore, op. cit., pp.778-9.

BBilsland v. Bilsland [1922] 1 W.W.R. 718. 
right of appeal. If, therefore, a right of appeal is inherent in the English Act, then it was introduced into British Columbia in 1867. This being done, it was competent for the province under its powers over administration of justice and procedure to set up machinery by which such a right could be exercised. As the right to appeal existed, then the incapacity provision of s. 57 which attached to such right was also in force though both were dormant, awaiting judicial machinery for their effective application.

On this view, the finding that s. 57 of the English Act applies to British Columbia is sound. The Supreme Court, however, should have clarified the precise method of its application. Specifically, s. 57 provided for a three month time limit for appeal commencing from the date of judgment. The British Columbia statute changed this to two months from the date of entry of the judgment. On the above reasoning, this seems to be intra vires though it is not without doubts. But s. 57 dealt with only one appeal. How, then, is it to apply to appeals to the Supreme Court of Canada? These are matters touching every divorce decree given in British Columbia and should have evoked elucidating comment from the Supreme Court.

Having decided that s. 57 applied to create an incapacity to marry during the time allowed for appealing, the court was then faced with the problem of deciding what effect to give to this incapacity when, during its subsistence, one party becomes domiciled in another jurisdiction - another province of Canada in the case here. This question had received the attention of other courts, and the most authoritative decision on it was that of the Australian High Court in Miller v. Teal. The approach of the Supreme Court of Canada to this issue was the traditional one, and-it might be added-a rather unimaginative and unsatisfactory one. The traditional approach was to attempt to arrive at a solution by stating the problem in a certain way. Thus, it was said, there were two possible views of a divorce decree with a concomitant incapacity to remarry: (1) That the decree, while restoring the single status, was conditional until the time limited for appealing had expired and consequently there was a residual incapacity to remarry which was a continuation of the incapacity that existed during the marriage; (2) That the decree dissolved the marriage for all purposes and the incapacity arose from a provision in the statute which was separate and distinct from the decree itself. The ease of deciding whether or not the incapacity should be given extra-territorial effect when the problem is so treated is obvious, for if the first view is adopted, then such effect follows automatically because under that view incapacity involved in the first marriage has not yet been removed. The second view, on the other hand, gives no such simple result but merely puts the question into sharper relief.

Unfortunately both the Supreme Court of Canada and the High Court of Australia adopt the first view without giving anything like a satisfactory reason for so doing. There is, of course, nothing wrong with saying the incapacity is residual and hence entitled to extra-territorial recognition if this is stated as a conclusion after a thorough consideration of the problem: But to say the incapacity is entitled to extra-territorial recognition because it is "residual incapa-

oMiller v. Teale (1954) 92 C.L.R. 406. 
city" is to confuse a conclusion of law with the reasons for it. This approach would be perfectly legitimate if the divorce decree were an organic or physical thing, but even then some scrutiny would be essential. But divorce is an intangible thing. It ends certain rights and duties and substitutes others. The question, therefore, should not be whether an incapacity following a divorce is residual or not, but rather what effect should a court give to the peculiar facts arising out of a divorce decree that is subject to reversal by appeal, the court being bound to recognize such reversal if it should occur. This is the real problem facing the court. It would be present even if the foreign law contained no statutory impediment to remarriage and even if the problem arose wholly within the jurisdiction of the court of the forum were there no such statutory incapacity in such jurisdiction. This is really the question posed by the foregoing second view of a divorce decree, though courts have generally failed to recognize this and have assumed that under the second view the incapacity was a mere in personam stacutory limitation on the party which was entitled to no extra-territorial recognition.

Stated in this way it is clear that the problem is not susceptible of an automatic solution. That is because this is a statement of a problem-a question, while the first view is largely a conclusion or an answet to the question. It is equally clear that the problem should have been canvassed by the dissenting Judges of the Supreme Court, for it arose with nearly equal force even after their conclusion that there was no statutory bar. The reason for this is that the situation created by the decree was really novel and had never been subjected to adjudication. The alternatives involved in these circumstances were concisely stated by Davey J.A. in the Court of Appeal where he said:

"It is a matter of policy affecting remarriage of the former spouses whether it is better to forbid marriage of the divorced persons before the time for appeal has expired on the pain of invalidity ... in order to prevent innecent persons being inveigled into a possible false marriage; or, on the other hand, whether it is better to uphold such marriages if the decree be not reversed." 10

That the conclusion to the question raised in this manner would coincide with that given under the "residual incapacity" doctrine on the facts here is hardly open to doubt, having in mind the past policy of the courts in relation to the family and also the policy of the legislature as manifested in these statutory prohibitions. Kitto J., in fact, so held in Miller v. Teale." It should also be noted that these suggestions, as to what the proper considerations in arriving at the decision in this case should have been, are in no way at variance with stare decisis, for here a situation arose requiring a creative approach by the common law in order to set up a rule, there being none in existence to cover the facts.

But however arrived at, the decision has been made. The question now arises, to what extent does it affect private international law? Here again the limitations of the "residual incapacity" doctrine are evident. By speaking the language of this doctrine the court may very well overlook the facts which gave rise to it. Thus it may be extended to cover recognition of all foreign incapacities arising on divorce which are not "penal" or "exemplary". To the

10 Densmore v. Densmore, op. cit., p. 265.

11 Miller v. Teal, op. cit., p. 419 et seq. 
extent that the court may construe such incapacities unrelated to appeals as not being "penal", etc., by applying the "residual incapacity" doctrine it may give recognition to foreign imposed incapacities for which there is no good reason to give recognition. That this is not just a remote possibility is indicated by the fact that the Australian Court (the majority) cited with approval a case ${ }^{12}$ where the doctrine was applied to recognize an incapacity to marry extending for two years after the decree-thus out of all proportion to the time limited for appeal. It is to be remembered that three Judges of the majority in the Supreme Court of Canada cited Miller v. Teale as a correct decision without any reservations.

It is submitted that the rule for such recognition, however, must be restricted to the facts of both Hellens v. Densmore and Miller v. Teale, i.e. to recognition of incapacities running concurrently with a right of appeal only. Besides the facts and some statements in these two cases supporting this view, it is also buttressed by the Privy Council judgment in Marsh v. Marsh ${ }^{13}$ which held that a decree absolute dissolves the marriage for all purposes notwithstanding the inability to remarry during the period for appeal. That a right to remarcy arises upon a dissolution of marriage even without an express grant is obvious from a reading of any modern Parliamentary Divorce which never grants a right to remarry to the guilty party, yet such right has never been questioned.

A few final points in the case warrant attention. Firstly, Rand J. did not subscribe to the "residual incapacity" doctrine of Miller v. Teale. His reasons are none the less dubious, however. He states that the incapacity imposed by the pre-confederation legislature is of the same force and effect as if passed by the Dominion Parliament for only the Dominion can pass such legislation now. It is therefore binding on all provinces and must be recognized by all Canadian courts. This reasoning is fallacious. For example, if by pre-confederation law British Columbia had a rule absolutely prohibiting marriage of parties there domiciled under the age of eighteen, there is no doubt whatever that such incapacity would not apply to a person originally domiciled in British Columbia after he has changed his domicile to Alberta. Yet on the above reasoning, such an incapacity would follow the person to Alberta. The reasoning appears to be an attempt to break down the boundaries of the provinces for some purposes relating to domicile that is either unjustified or insufficiently explained by the learned Justice.

Secondly, the majority of the Court of Appeal manifested an unusually insular attitude in their refusal to consider what the law of Alberta was relating to recognition of foreign incapacities to marry. In the absence of a particular statute binding on Alberta only, it was clear that the Alberta common law conflicts rule would be the same as that of British Columbia. Both would be bound by any ruling of the Supreme Court of Canada which in turn would follow any existing English precedent. Furthermore, there is a rule well known to the courts that, in the absence of evidence, foreign law may be assumed to

${ }^{12 B o u t t c h e r ~ v . ~ B o e r t c h e r ~[1949] ~ W . ~ N . ~} 83$.

${ }^{13}$ Marsh v. Marsh [1945] A. C. 271. 
be the same as domestic law. The majority of the Court of Appeal completely distegarded this rule.

Finally, Sidney Smith J.A. was prepared to hold the marriage void even if the law of the parties' respective domiciles fully permitted such marriage. His reason was that as the incapacity was imposed by the forum, marriage in violation of it should be regarded as void (with emphasis on "illegal") by a court of the forum. This is a sad example of uninhibited provincial pride taking precedence over established rules of law. It was contrary to English authority (eg. In re Paine ${ }^{14}$ ) and was quite properly disregarded in the Supreme Court of Canada where the law of the domicile of the parties was applied instead. On the question whether the matrimonial domicile or the dual domicile rule respecting capacity to marry is the correct one, this case is of slight authority - both rules being satisfied by the facts. The dual domicile rule was in fact applied but it was not expressly referred to by that name.

14In re Poine [1940] Ch. 46. 